\title{
THE INFLUENCE OF TRANSFORMATIONAL LEADERSHIP ON SERVICE COMMITMENT (Survey in Dinas Kependudukan, Catatan Sipil dan Tenaga Kerja at Cirebon City)
}

\author{
Candradewini \\ (Dosen Administrasi Niaga FISIP UNPAD)
}

\begin{abstract}
Abstrak
The purpose of this research is to know (1) the implementation of transformational leadership; (2) the service commitment; and (3) the influence of transformational leadership on service commitment. There are two research variables, transformational leadership $(X)$ and service commitment $(Y)$.

This research use study method with explanatory research to explain causal relation among variables. Address the research objective it is conducted a descriptive and verification analysis by regression analysis as means of its analysis. The research was conducted on whole employees who worked in Dinas Kependudukan, Catatan Sipil dan Tenaga Kerja Cirebon City in which samples is all of its employee. The transformational leadership variable used an indicator whose was suggested by Bass, whereas the service commitment variable used an indicator whose was suggested by Sutopo and Suryanto.

Generally, the results of research concluded that transformational leadership which was conducted existing in high category and the service commitment existed in high category too. Using the regression as means of verification analysis indicated that transformational leadership have positive effect on service commitment.
\end{abstract}

Keywords: Transformational Leadership and Service Commitment

\section{PENDAHULUAN}

Indonesia memiliki jumlah penduduk yang besar, jumlah ini belum diikuti oleh tingkat intelektualitas yang tinggi dan penyebaran penduduk yang merata di setiap pulau. Keadaan ini perlu segera ditanggulangi, antara lain membuat program transmigrasi, keluarga berencana, pencatatan kependudukan, dan pendidikan yang harus dikelola melalui sistem administrasi dan manajemen yang tepat. Penanggulangan ini dilakukan untuk menekan berbagai masalah yang timbul seperti kepadatan di Pulau Jawa dan Bali, pengganguran, dan hal lain yang terjadi. Pada gilirannya, keberhasilan program-program tersebut tidak terlepas dari sumber daya manusia sebagai pelaksana, yaitu aparatur pemerintah.

Dinas Kependudukan, Catatan Sipil dan Tenaga Kerja Kota Cirebon, adalah instansi yang bertugas mengelola dan bertanggung jawab terhadap masalah kependudukan, catatan sipil, dan tenaga kerja, khususnya di Kota Cirebon. Keberadaan Dinas harus mampu mengantisipasi dan beradaptasi terhadap tantangan perubahan dan dapat memecahkan masalah-masalah kependudukan, catatan sipil, dan tenaga kerja.
Dalam rangka menjawab tantangan perubahan tersebut, Dinas Kependudukan, Catatan Sipil dan Tenaga Kerja Kota Cirebon harus mampu melaksanakan tugas pokoknya dengan penuh kesungguhan dan tanggung jawab berdasarkan visi dan misi Dinas yang telah ditetapkan.

Dalam rangka melaksanakan tugas pokok dan fungsi, Dinas Kependudukan, Catatan Sipil dan Tenaga Kerja Kota Cirebon harus mampu mengelola seluruh sumber daya yang dimilikinya termasuk sumber daya manusia dalam hal ini pegawai. Pegawai sebagai anggota organisasi, membutuhkan sosok pemimpin yang memiliki kepemimpinan yang baik dalam rangka mencapai efektivitas pelaksanaan pekerjaannya. Dinas Kependudukan, Catatan Sipil dan Tenaga Kerja Kota Cirebon dipimpin oleh seorang Kepala Dinas yang mempunyai tugas pokok melaksanakan tugas desentralisasi di bidang kependudukan, catatan sipil dan tenaga kerja. Kepala Dinas mempunyai fungsi merumuskan kebijakan dan memimpin penyelenggaraan tugas di bidang kependudukan, catatan sipil dan tenaga kerja.

Proses kepemimpinan ini diperlukan sebagai proses untuk mempengaruhi kelompok untuk mencapai tujuan yang telah ditetapkan. Munculnya 
kepemimpinan merupakan fenomena sosial yang tidak dapat terlepas dari konteks situasional yang lebih luas. Kepemimpinan yang berlaku pada suatu kelompok dapat menunjukkan karakteristik sosial, ekonomi, dan budaya dari kelompok tersebut. Secara umum, faktor kepemimpinan lebih menekankan pada visi, membangun kepercayaan untuk mencapai tujuan yang telah ditetapkan dan memotivasi kelompok untuk melakukan tindakan yang sesuai. Pemimpin mempunyai peran dalam menumbuhkan komitmen pekerja terhadap organisasi yang akan meningkatkan usaha bawahan sehingga kualitas dan produktivitas perusahaan dapat tercapai (Yukl, 1998). Komitmen pegawai dalam melaksanakan tugasnya menjadi faktor penentu dalam mencapai kinerja pelayanan yang prima. Keikutsertaan para pegawai dalam memberikan pelayanan yang berkualitas dan selalu berusaha untuk meningkatkan pelayanan yang diberikan merupakan inti dari komitmen pelayanan pegawai (Peccei dan Rosenthal, 1997).

Konsep komitmen pelayanan pelanggan didefinisikan sebagai hubungan kecenderungan individu untuk memberikan perbaikan secara terus menerus dan berusaha sungguh-sungguh untuk keuntungan pelanggan (Peccei dan Rosenthal, 1997). Tidak akan terjadi pelayanan yang berkualitas, apabila tidak ada komitmen pegawai untuk melakukannya, karena itu pihak manajemen harus mampu menanamkan komitmen yang kuat kepada pegawai dalam rangka menciptakan pelayanan yang berkualitas.

Berdasarkan pengamatan dan wawancara awal, ditemukan bahwa komitmen pelayanan yang ditunjukkan oleh pegawai Dinas Kependudukan, Catatan Sipil dan Tenaga Kerja Kota Cirebon masih rendah, yang terlihat dari indikasi masalah berikut.

1. Komitmen untuk memberikan pelayanan terbaik belum optimal, tampak dari pembuatan akta perkawinan yang keliru, yang meloloskan ijin perkawinan bagi mempelai yang masih di bawah umur.

2. Kesalahan penulisan nama orang tua pada akta kelahiran karena tidak lengkap syarat pembuatan akta seperti surat nikah orang tua, keterangan bidan dan Kelurahan.

3. Pegawai yang indisipliner, sering terlambat apel setiap hari Senin, upaya disiplin tidak menunjukkan usaha mengubah kebiasaan lambat kerja.

4. Upaya menyebarluaskan informasi mengenai prosedur dan syarat pembuatan akta catatan sipil belum optimal, seperti terlihat dari masih banyak warga masyarakat yang tidak mengetahui pembuatan akta catatan sipil itu.

5. Upaya koordinasi dengan instansi lain kurang optimal, seperti dengan Kecamatan dalam memberikan laporan kependudukan yang terlambat.

Zeithaml, Parasuraman, dan Berry (1990 : 4) menjelaskan dalam kepemimpinan setiap tahap organisasi memberikan inspirasi untuk membentuk para pelayan yang memiliki komitmen bahwa "The key is genuine service leadership at all levels of an organization-leadership that offers the direction and inspiration to sustain committed servers." Kepemimpinan transformasional kerapkali diidentifikasi melalui dampaknya terhadap sikap, nilai, asumsi, dan komitmen para pengikut itu (Yukl, 1998).

Menurut Sosik, Kahai, dan Avolio (dalam Mc.Shane and Glinow, 2003 : 433) bahwa transformational leadership membuat suatu perbedaan menurut studi perilaku organisasi. Bawahan lebih puas dan memiliki komitmen yang tinggi terhadap organisasi di bawah transformational leadership. Mereka juga melaksanakan tugasnya dengan lebih baik, dan membuat keputusan yang lebih baik dan kreatif. Konsep kepemimpinan transformasional bukan hanya ditujukan untuk mencapai suatu tujuan saja, tetapi merupakan suatu upaya untuk memunculkan usaha terbaik dalam mencapai keunggulan, sehingga menjadikan organisasi makin mampu bertahan di dalam kompetisi yang semakin tajam. Menurut Bass (dalam Yukl, 1998 : 298) para pemimpin transformasional dapat ditemukan dalam organisasi mana saja pada tingkatan mana saja. Selain itu, Bass (1990) menyatakan bahwa kepemimpinan transformasional paling cocok untuk level manajemen puncak. Bass (1990 : 218) mendeskripsikan hasil survei terhadap 1500 general manager, para pemimpin tim teknis, para administrator pemerintahan dan pendidikan, para manajer menengah atas, dan para pejabat angkatan darat Amerika Serikat. $\mathrm{Hal}$ ini menggambarkan bawahan merasa penerapan gaya kepemimpinan transformasional lebih efektif 
dan menimbulkan upaya yang lebih keras dalam melakukan pekerjaan serta lebih memberikan kontribusi terhadap organisasi. Bass (dalam Luthans, 2002 : 592) mengemukakan bahwa melalui kepemimpinan transformasional, seorang pemimpin dapat mentransformasikan bawahannya melalui kharisma, inspirasi, stimulasi intelektual dan pertimbangan individu.

Berdasarkan wawancara awal dengan beberapa pegawai, diketahui bahwa Kepala Dinas menjalankan kepemimpinan transformasional. Menurut beberapa pegawai, Kepala Dinas membuat terobosan-terobosan baru dalam tata cara dan prosedur kerja. Diantaranya, pada kepemimpinan Kepala Dinas terdahulu, pegawai tidak memiliki buku laporan kinerja individu, sementara sekarang, Kepala Dinas membuat aturan setiap pegawai harus membuat catatan kegiatan dalam bentuk buku laporan kinerja individu. Selain itu, para pegawai merasa bangga dan hormat terhadap Kepala Dinas karena memiliki ketegasan dalam menjalankan kepemimpinannya. Namun rasa bangga dan hormat masih disertai kekakuan sehingga menimbulkan rasa sungkan dalam diri pegawai. Komitmen pelayanan yang rendah salah satunya disebabkan oleh kepemimpinan transformasional yang belum optimal dilakukan oleh Kepala Dinas.

Kepemimpinan transformasional Kepala Dinas terlihat juga dengan memberikan keleluasaan kepada pegawai untuk memecahkan permasalahan pekerjaan sesuai dengan wewenang dan tanggung jawabnya. Namun kelemahan lain dari kepemimpinannya yaitu belum mampu mewujudkan keinginan pegawai untuk mempersatukan pegawai dalam satu lokasi kerja. Selama ini, Dinas Kependudukan, Catatan Sipil dan Tenaga Kerja Kota Cirebon terpisah dalam dua lokasi yaitu di Jl. Brigjen Darsono dan JI. Cipto Mangunkusumo sehingga menghambat proses koordinasi antara pimpinan dengan staf maupun antar bagian satu dengan yang lain.

Tampak jelas ketika Kepala Dinas saat ini, mengubah kebiasaan dan nilai-nilai konvensional yang selama ini berlangsung di Dinas Kependudukan, Catatan Sipil dan Tenaga Kerja Kota Cirebon. Kepala Dinas membuka kesempatan yang seluas-luasnya kepada seluruh pegawai untuk mengajukan saran, kritik bahkan ketidaksetujuan apabila berlainan pendapat dengannya.
Bertitik tolak dari latar belakang penelitian dapat dirumuskan sebuah rumusan masalah penelitian (problem statements) yaitu komitmen pelayanan pegawai Dinas Kependudukan, Catatan Sipil dan Tenaga Kerja Kota Cirebon masih rendah, salah satunya karena pengaruh kepemimpinan transformasional yang dilakukan oleh kepala dinas belum berjalan secara optimal.

\section{KERANGKA PEMIKIRAN DAN HIPOTESIS}

\subsection{Kerangka Pemikiran}

Komitmen pelayanan merupakan hubungan kecenderungan individu untuk memberikan perbaikan secara terus-menerus dan berusaha sungguh-sungguh untuk keuntungan pelanggan (Peccei and Rosenthal, 1997). Berdasarkan pendapat tersebut, dapat dikatakan bahwa seorang pegawai yang memiliki komitmen terhadap pelayanan, maka pegawai akan melakukan usaha yang sungguh-sungguh dalam melakukan pelayanan dan selalu melakukan perbaikan terhadap pelayanan yang dilakukannya.

Komitmen pegawai dalam melakukan pekerjaannya dipengaruhi oleh berbagai faktor diantaranya budaya organisasi. Robbins (2001: 515) yang mengemukakan bahwa "Budaya mempermudah timbulnya komitmen pada sesuatu yang lebih luas daripada kepentingan diri individual seseorang". Pendapat Robbins tersebut menyiratkan bahwa budaya akan menimbulkan komitmen karyawan terhadap tujuan organisasi yang lebih besar daripada tujuan individu.

Elzbieta Sikorska-Simmons (2005) melakukan penelitian berjudul "Predictors of Organizational Commitment Among Staff in Assisted Living." Hasil penelitian menunjukkan budaya organisasi, kepuasan kerja dan pendidikan merupakan peramal (predictor) dari komitmen pegawai.

Peramal (predictor) lain yang mempengaruhi komitmen pegawai adalah kepemimpinan transformasional. Bass (dalam Griffith, 2004) menyatakan bahwa untuk membangun komitmen anggota kelompok dalam rangka mencapai sasaran dan tujuan, para pemimpin transformasional melalui hubungan interpersonal berusaha memenuhi kebutuhan moral dan psikologis manusia.

Dimensi inspirasi yang dilakukan oleh seorang pemimpin transformasional dapat membentuk para 
pelayan yang memiliki komitmen. "The key is genuine service leadership at all levels of an organization-leadership that offers the direction and inspiration to sustain committed servers." Zeithaml, Parasuraman, dan Berry (1990). Kepemimpinan transformasional ialah suatu model kepemimpinan yang menunjukkan seorang pemimpin mampu mengartikulasikan visi masa depan organisasi yang realistis, menstimulasi bawahan dengan cara yang intelektual dan menaruh perhatian terhadap perbedaanperbedaan yang dimiliki bawahannya (Bass, 1990). Dimensi kepemimpinan transformasional, menurut Bass, 1990 (dalam Luthans, 2002: 592) terdiri dari: karisma (charisma), inspirasi (inspiration), perangsangan intelektual (intellectual stimulation) dan pertimbangan individu (individual consideration).

Charisma, yang didefinisikan sebagai kemampuan pemimpin untuk membangkitkan kebanggaan, kepercayaan dan rasa hormat terhadap bawahannya dan mampu mengkomunikasikan secara efektif pengertian misi dan visi organisasi yang dipimpinnya. Inspiration, menggambarkan sejauhmana seorang pemimpin mengkomunikasikan sebuah visi yang menarik, menggunakan simbol-simbol untuk memfokuskan usaha-usaha bawahan dan mengekspresikan tujuan-tujuan penting dengan cara yang sederhana. Intellectual stimulation, merupakan perilaku pemimpin yang mendorong bawahannya untuk selalu berinovasi dan kreatif terhadap pemecahan masalah-masalah yang dihadapi, menawarkan ide-ide baru guna merangsang bawahannya untuk memikirkan kembali cara-cara yang lama dalam menyelesaikan pekerjaan dan mempengaruhi para bawahannya untuk memandang masalah-masalah tersebut dari perspektif yang baru. Individualized consideration, merupakan perilaku pemimpin yang selalu peduli terhadap pengembangan kemampuan atau karir bawahannya, memperlakukan bawahan sebagai seorang individu, berusaha untuk mengerti keinginan bawahan dan berfungsi sebagai penasehat dan pelatih.

Kane, Tremble dan Koh et al., (dalam Griffith, 2004) menjelaskan bahwa komitmen anggota kelompok, upaya ekstra dan motivasi dalam pekerjaan mereka, dan komitmen terhadap organisasi berhubungan positif dengan keseluruhan proses dari kepemimpinan transformasional, yang bernama inspirasi (inspirations), pertimbangan (considerations) dan perangsangan (stimulation). Pendapat ini menjelaskan bahwa dimensi inspirasi dapat meningkatkan komitmen pegawai yang ditunjukkan dengan upaya ekstra dan motivasi dalam melaksanakan pekerjaan. Peningkatan komitmen pegawai dalam melaksanakan pekerjaannya juga dipengaruhi oleh pertimbangan pemimpin terhadap pegawai dan kemampuan pemimpin dalam merangsang (stimulating) pegawai agar bekerja dengan usaha yang sungguh-sungguh dan penuh motivasi.

Konsep komitmen pelayanan pelanggan didefinisikan sebagai hubungan kecenderungan individu untuk memberikan perbaikan secara terus menerus dan berusaha sungguh-sungguh untuk keuntungan pelanggan (Peccei dan Rosenthal, 1997).

Komitmen pelayanan merupakan pedoman untuk mencapai kesuksesan dalam memperkenalkan inisiatif pelayanan (Sutopo dan Suryanto, $2003: 20$ ).

Variabel penelitian komitmen pelayanan berdasarkan landasan konseptual yang dikembangkan oleh Sutopo dan Suryanto (2003):
1.Kejelasan
2.Konsistensi
3.Komunikasi
4.Komitmen

Berdasarkan kerangka pemikiran penelitian, gambaran paradigma konseptual penelitian adalah sebagai berikut:

\begin{tabular}{|l|l|}
\hline \multicolumn{1}{|c|}{ Kepemimpinan } \\
Transformasional \\
1. Charisma \\
2. Inspiration \\
3. Intelletual stimulation \\
4. Individual \\
consideration \\
Bass (Dalam Luthans, \\
2002)
\end{tabular}$\longrightarrow \begin{aligned} & \text { Komitmen Pelayanan } \\
& \text { 1. Kejelasan } \\
& \text { 2. Konsistensi } \\
& \text { 3. Komunikasi } \\
& \text { 4. Komitmen } \\
& \text { Sutopo dan Suryanto } \\
& (2003)\end{aligned}$

\section{Gambar 2.1. Paradigma Konseptual Penelitian}

\subsection{Hipotesis}

Berdasarkan kerangka pemikiran penelitian, maka hipotesis yang diajukan adalah sebagai berikut: 
1. Besarnya pengaruh kepemimpinan transformasional terhadap komitmen pelayanan di Dinas Kependudukan, Catatan Sipil dan Tenaga Kerja Kota Cirebon ditentukan oleh dimensi karisma, inspirasi, perangsangan intelektual dan pertimbangan terhadap individu.

2. Besarnya pengaruh dimensi karisma terhadap komitmen pelayanan di Dinas Kependudukan, Catatan Sipil dan Tenaga Kerja Kota Cirebon ditentukan oleh indikatorindikator dari dimensi tersebut.

3. Besarnya pengaruh dimensi inspirasi terhadap komitmen pelayanan di Dinas Kependudukan, Catatan Sipil dan Tenaga Kerja Kota Cirebon ditentukan oleh indikatorindikator dari dimensi tersebut.

4. Besarnya pengaruh dimensi perangsangan intelektual terhadap komitmen pelayanan di Dinas Kependudukan, Catatan Sipil dan Tenaga Kerja Kota Cirebon ditentukan oleh indikator-indikator dari dimensi tersebut.

Besarnya pengaruh dimensi pertimbangan terhadap individu terhadap komitmen pelayanan di Dinas Kependudukan, Catatan Sipil dan Tenaga Kerja Kota Cirebon ditentukan oleh indikatorindikator dari dimensi tersebut.

\section{METODE PENELITIAN}

Jenis penelitian ini adalah deskriptif dan verifikatif (Singarimbun dan Effendi, $1989: 4$ ) untuk memperoleh gambaran tentang kepemimpinan transformasional dan komitmen pelayanan di Dinas Kependudukan, Catatan Sipil dan Tenaga Kerja Kota Cirebon. Analisis verifikatif untuk menguji kebenaran dari suatu hipotesis melalui pengolahan data yang diperoleh dari pengumpulan data dari responden yang dilakukan secara langsung di Dinas Kependudukan, Catatan Sipil dan Tenaga Kerja Kota Cirebon.

Metode yang digunakan dalam penelitian ini adalah studi serta menggunakan tipe penjelasan (explanatory research), untuk memberikan penjelasan hubungan kausal antara variabelvariabel melalui pengujian hipotesis.

Penelitian ini berfokus pada kepemimpinan transformasional yang dilakukan oleh Kepala Dinas, sehingga populasi penelitian adalah seluruh bawahan Kepala Dinas yang berjumlah 80 orang. Adapun sampel yang diambil menggunakan teknik sampling sensus, yaitu seluruh anggota populasi dijadikan sampel. Keadaan pegawai berdasarkan golongan pada Dinas Kependudukan, Catatan Sipil dan Tenaga Kerja Kota Cirebon.

Data yang digunakan dalam penelitian ini adalah data primer dan data sekunder. Data primer diperoleh dari pegawai dengan cara menyebarkan kuesioner kepada responden. Kuesioner tersebut disusun berdasarkan skala ordinal yang berpedoman pada Likert Summated Rating. Data sekunder diperoleh dengan cara:

1. Melakukan wawancara dengan responden.

2. Studi dokumentasi, yaitu suatu teknik pengumpulan data sekunder yang ada hubungannya dengan topik penelitian. Data ini meliputi sejarah dinas, tupoksi dinas dan semua unit kerjanya, laporan tahunan dinas, keadaan pegawai, dan data lain yang berkaitan dengan obyek penelitian.

\section{HASIL PENELITIAN DAN PEMBAHASAN}

Pengukuran terhadap pelaksanaan kepemimpinan transformasional dilakukan dengan menggunakan indikator-indikator yang ditentukan berdasarkan dimensi-dimensi variabel kepemimpinan transformasional. Dimensi variable kepemimpinan transformasional adalah karisma, inspirasi, perangsangan intelektual, dan pertimbangan individu.

Komitmen pelayanan para pegawai di lingkungan Dinas Kependudukan, Catatan Sipil dan Tenaga Kerja Kota Cirebon diukur dengan menggunakan indikatorindikator. Indikator disusun berdasarkan dimensidimensi komitmen pelayanan yaitu kejelasan, konsistensi, komunikasi, komitmen.

Hasil pengujian reliabilitas menunjukkan bahwa dimensi kejelasan dan komunikasi dikategorikan cukup reliabel dan dimensi konsistensi serta komitmen reliabel. Hasil ini memberikan gambaran bahwa data hasil dari kuesioner penelitian ini dapat digunakan lebih lanjut karena sudah terbukti bahwa kuesioner penelitian ini memiliki ringkat reliabilitas yang cukup memuaskan.

Berdasarkan hasil perhitungan masing-masing pernyataan dan masing-masing dimensi, maka kepemimpinan transformasional yang dilakukan oleh Kepala Dinas Kependudukan, Catatan Sipil dan Tenaga Kerja Kota Cirebon berada pada kategori tinggi atau baik. Dimensi yang memiliki skor terendah adalah dimensi pertimbangan individu (individual consideration). 
Tabel 4.1 Akumulasi Jawaban Responden Terhadap Kepemimpinan Transformasional

\begin{tabular}{|c|l|c|c|}
\hline \hline No. & \multicolumn{1}{|c|}{ Indikator } & $\begin{array}{c}\text { Skor } \\
\text { Total }\end{array}$ & $\begin{array}{c}\text { Rasio } \\
(\%)\end{array}$ \\
\hline \hline 1 & Kharisma & 1146 & 71,6 \\
\hline 2 & Inspirasi & 1416 & 70,8 \\
\hline 3 & Perangsangan Intelektual & 1265 & 79,1 \\
\hline 4 & Pertimbangan Individual & 1123 & 70,2 \\
\hline \hline \multicolumn{2}{r|}{ Total } & 4950 & 72,8 \\
\hline \hline
\end{tabular}

Perangsangan intelektual yang dilakukan oleh Kepala Dinas berjalan dengan baik. Hal ini terlihat dari hasil akumulasi sebanyak 79,1 persen atau angka tertinggi dari seluruh dimensi kepemimpinan transformasional yang dilakukan Kepala Dinas.

Adapun hasil akumulasi indikator-indikator komitmen pelayanan, diperoleh skor 69,7. Dengan demikian dapat dikatakan bahwa komitmen pelayanan pegawai Dinas Kependudukan, Catatan Sipil dan Tenaga Kerja termasuk kategori tinggi atau baik. Namun demikian hasil ini kalau dilihat dari skor total posisinya hanya sedikit di atas skor batas bawah untuk kategori tinggi atau baik.

Tabel 4.2.

Akumulasi Jawaban Responden Terhadap Komitmen Pelayanan

\begin{tabular}{|c|l|c|c|}
\hline \hline No. & \multicolumn{1}{|c|}{ Indikator } & $\begin{array}{c}\text { Skor } \\
\text { Total }\end{array}$ & $\begin{array}{c}\text { Rasio } \\
(\%)\end{array}$ \\
\hline \hline 1 & Kejelasan & 1123 & 70,2 \\
\hline 2 & Konsistensi & 797 & 66,4 \\
\hline 3 & Komunikasi & 565 & 70,6 \\
\hline 4 & Komitmen & 1977 & 70,6 \\
\hline \multicolumn{2}{|r|}{ Total } & 4462 & 69,7 \\
\hline \hline
\end{tabular}

Secara umum komitmen pelayanan berada pada kategori baik atau tinggi, namun untuk dimensi konsistensi masih berada pada kategori cukup. Hal ini menunjukkan perlu ditingkatkan lagi konsistensi pegawai dalam melayani masyarakat Kota Cirebon.

Berdasarkan hasil penelitian, kepemimpinan transformasional yang dilakukan oleh Kepala Dinas Kependudukan, Catatan Sipil dan Tenaga Kerja Kota Cirebon berada pada kategori tinggi atau baik. Dimensi yang memiliki skor terendah adalah dimensi pertimbangan individu (individual consideration).

Perangsangan intelektual yang dilakukan oleh Kepala Dinas berjalan dengan baik. Hal ini terlihat dari hasil akumulasi sebanyak 79,1 persen atau angka tertinggi dari seluruh dimensi kepemimpinan transformasional yang dilakukan Kepala Dinas.

Komitmen pelayanan pegawai Dinas Kependudukan, Catatan Sipil dan Tenaga Kerja Kota Cirebon termasuk kategori tinggi atau baik. Namun demikian hasil ini kalau dilihat dari skor total, posisinya hanya sedikit di atas skor batas bawah untuk kategori tinggi atau baik. Secara umum komitmen pelayanan berada pada kategori baik atau tinggi, namun untuk dimensi konsistensi masih berada pada kategori cukup. Hal ini menunjukkan perlu ditingkatkan lagi konsistensi pegawai dalam melayani masyarakat Kota Cirebon.

Salah satu tujuan penelitian ini adalah mengetahui seberapa besar pengaruh dari dimensi-dimensi kepemimpinan tranformasional yaitu dimensi kharisma (X1), inspirasi (X2), perangsangan intelektual (X3), dan pengembangan individual $(X 4)$ terhadap komitmen pelayanan $(Y)$ baik secara simultan maupun secara parsial. Teknis analisis yang digunakan adalah analisis jalur (path analysis).

Sebelum dapat menggunakan teknis analisis ini, ada beberapa asumsi yang harus terpenuhi diantarnya adalah data dalam skala pengukuran minimal interval, dan variabel dependen $(Y)$ harus mengikuti distribusi normal.

Hipotesis konseptual yang diajukan oleh penulis dapat digambarkan dalam diagram jalur sebagai berikut :

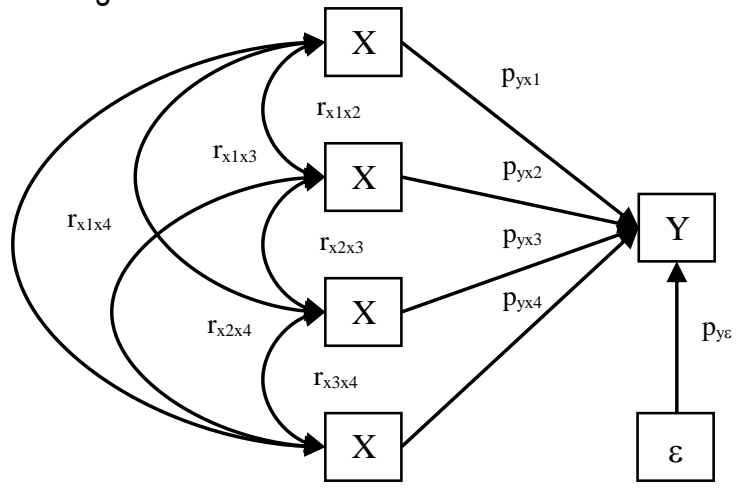

Gambar 4.1. Diagram Jalur Penelitian

Strategic, Volume 9, Nomor 18, September 2010 
Diagram jalur di atas dapat dituliskan dalam persamaan statistik sebagai berikut

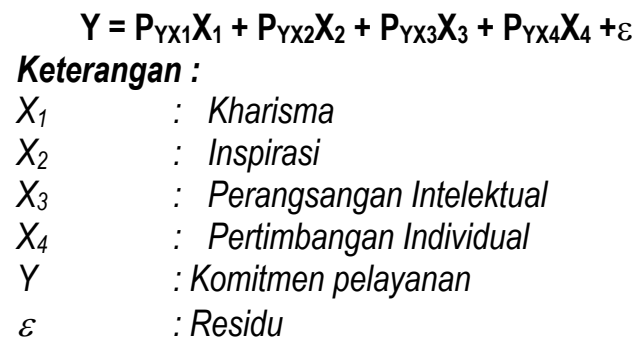

Tabel 4.3 Akumulasi Pengaruh Dari Kepemimpinan transformasional Terhadap Komitmen pelayanan

\begin{tabular}{|l|c|}
\hline \multicolumn{1}{|c|}{ Dimensi } & $\begin{array}{c}\text { Pengaruh Total } \\
\text { Terhadap } \\
\text { Komitmen } \\
\text { pelayanan Pada } \\
(\%)\end{array}$ \\
\hline \hline Kharisma $\left(X_{1}\right)$ & 13,460 \\
\hline Inspirasi $\left(X_{2}\right)$ & 14,034 \\
\hline Perangsangan Intelektual $\left(X_{3}\right)$ & 12,604 \\
\hline Pertimbangan Individual $\left(X_{4}\right)$ & 9,663 \\
\hline \hline Total Pengaruh & 49,761 \\
\hline \hline
\end{tabular}

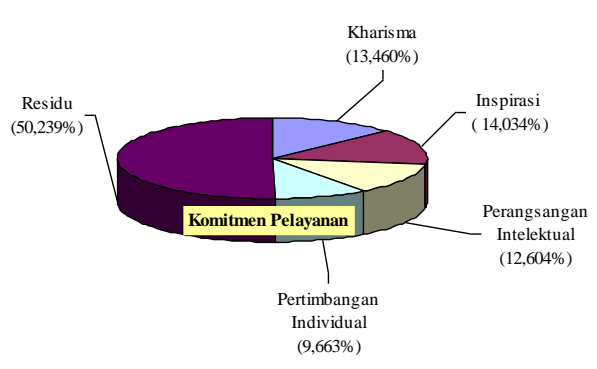

Gambar 4.2

Pengaruh Masing-masing Dimensi Kepemimpinan Tranformasional

Dari hasil perhitungan dan analisis diketahui dimana koefisien jalur tidak nol, menunjukkan adanya pengaruh dari dimensi-dimensi kepemimpinan tranformasional terhadap komitmen pelayanan di Dinas Kependudukan, Catatan Sipil dan Tenaga Kerja Kota Cirebon, dengan total pengaruh dari semua dimensi terhadap komitmen pelayanan sebesar $49,761 \%$ dan pengaruh variabel lain yang tidak terlibat dalam penelitain ini sebesar 50,239\%. Pegaruh terbesar diberikan oleh dimensi Inspirasi total pengaruh sebesar $14,034 \%$, selanjutnya pengaruh terbesar kedua diberikan oleh dimensi kharisam yaitu sebesar $13,460 \%$, dan selanjutnya dimensi perangsangan intelektual dengan total pengaruh $12,604 \%$ dan pengaruh terkecil disumbangkan oleh dimensi pertimbangan individual dengan besar pengaruh sebesar $9,663 \%$.

\section{KESIMPULAN DAN SARAN}

\subsection{Kesimpulan}

Berdasarkan tujuan penelitian yang telah dikemukakan sebelumnya dan berdasarkan hasil penelitian dan pembahasan mengenai Pengaruh Kepemimpinan Transformasional terhadap Komitmen Pelayanan (Studi pada Dinas Kependudukan, Catatan Sipil dan Tenaga Kerja Kota Cirebon) maka dapat ditarik kesimpulan sebagai berikut:

1. Hasil analisis deskriptif menunjukkan bahwa secara umum kepemimpinan transformasional yang dilaksanakan oleh Kepala Dinas pada Dinas Kependudukan, Catatan Sipil dan Tenaga Kerja Kota Cirebon termasuk dalam kategori tinggi atau baik. Namun demikian dimensi pertimbangan individual skornya paling rendah hanya sedikit di atas batas bawah kategori tinggi atau baik. Hal ini disebabkan ada salah satu indikator dimensi pertimbangan individual yang masuk kategori cukup yaitu berkomunikasi dan berinteraksi secara personal. Hal ini ditunjukkan dari rasa sungkan yang terlalu besar terhadap Kepala Dinas dan berakibat pada terhambatnya komunikasi secara personal sehingga menghambat pula terhadap penyelesaian pekerjaan.

2. Secara umum komitmen pelayanan pegawai di Lingkungan Dinas Kependudukan, Catatan Sipil dan Tenaga Kerja Kota Cirebon berada pada kategori tinggi atau baik. Namun demikian khusus untuk dimensi konsistensi masih berada pada kategori cukup. Untuk dimensi konsistensi, indikator konsistensi pegawai dalam melaksanakan peraturan dan prosedur hanya berada pada kategori cukup. Masih ada peraturan dan prosedur pelayanan yang tidak dijalankan secara utuh oleh pegawai. 
3. Hasil perhitungan dan analisis data menunjukkan terdapat pengaruh kepemimpinan tranformasional terhadap komitmen pelayanan di Dinas Kependudukan, Catatan Sipil dan Tenaga Kerja Kota Cirebon, dengan total pengaruh sebesar $49,761 \%$, yang berada pada kategori kuat. Komitmen pelayanan di Dinas Kependudukan, Catatan Sipil dan Tenaga Kerja Kota Cirebon sebagian besar dipengaruhi oleh faktor kepemimpinan transformasional yang dilakukan oleh Kepala Dinas. Pengaruh variabel lain yang tidak terlibat dalam penelitian ini sebesar 50,239\%. Pegaruh terbesar diberikan oleh dimensi inspirasi total pengaruh sebesar $14,034 \%$, selanjutnya pengaruh terbesar kedua diberikan oleh dimensi kharisma yaitu sebesar $13,460 \%$, dan selanjutnya dimensi perangsangan intelektual dengan total pengaruh $12,604 \%$ serta pengaruh terkecil disumbangkan oleh dimensi pertimbangan individual dengan besar pengaruh sebesar 9,663\%. Hasil koefisien analisis jalur tersebut menunjukkan bahwa baik secara parsial, maupun simultan kepemimpinan transformasional berpengaruh kuat terhadap komitmen pelayanan pada Dinas Kependudukan, Catatan Sipil dan Tenaga Kerja Kota Cirebon. Dengan demikian hipotesis penelitian diterima.

\subsection{Saran}

Berdasarkan penelitian yang dilakukan, penulis mengajukan beberapa saran yang berkaitan dengan penelitian ini.

1. Kepala Dinas hendaknya meningkatkan kemampuannya dalam melaksanakan kepemimpinan transformasional. Kepala Dinas dengan cara membuat suasana lebih hangat dan akrab agar pegawai tidak sungkan melakukan komunikasi dan interaksi secara personal dengan Kepala Dinas.

2. Konsistensi pegawai dalam menerapkan peraturan dan prosedur pelayanan seharusnya ditingkatkan. Hal ini dapat dilakukan dengan memberikan pemahaman mengenai peraturan dan prosedur serta penegakkan disiplin di lingkungan dinas.

Pengaruh kepemimpinan transformasional terhadap komitmen pelayanan berada pada kategori kuat. Namun demikian 50,239\% dipengaruhi faktor lain. Pada kesempatan ini penulis memberikan saran meneliti faktor lain, misalnya budaya organisasi dan pelatihan terhadap komitmen pelayanan.

\section{DAFTAR PUSTAKA}

Bass, B. M \& Avolio, B, J. 1990. Developing Transformational Leadership Journal of European Industrial Training. 14, 21-27.

Sikorska-Simmons, Elzbieta. 2005. Predictors of Organizational Commitment Among Staff in Assisted Living. The Gerontologist Society of America 45:196-205

Griffith, James. 2004. Relation of Principal Transformational Leadership to School Stafs Job Satisfaction, Staf Turnover and School Performance. Journal of Educational Administration.

Harun Al Rasyid. 1994. Teknik Penarikan Sampel dan Penyusunan Skala. Bandung.

Husein Umar. 2000. Riset Sumber Daya Manusia Dalam Organisasi. Jakarta: Gramedia Pustaka Utama.

Luthans, F, 2002, Organizational Behavior, 9th Edition, New York: McGraw-Hill.

Masri Singarimbun \& Sofyan Effendi. 1989. Metode Penelitian Survei. Jakarta: LP3S.

Mc. Shane, Steven L \& Mary Ann Von Glinow. 2003. Organizational Behavior, Second Edition. New York: McGraw-Hill.

Peccei \& Rosenthal. 1997. The Antecedent of Employee Commitment to Customer Service, International Journal of Human Resources Management.

Robbins, S., P. 2001. Organizational Behavior,. Ninth Edition, New Jersey: Prentice Hall, Upper Saddle River.

Sugiyono. 1997. Metode Penelitian Administrasi.

Bandung Alfabeta.

Sutopo dan Adi Suryanto. 2003. Pelayanan Prima. Jakarta: LAN RI.

Yukl, Gary A. 1998. Kepemimpinan dalam Organisasi, (Edisi Terjemahan Bahasa Indonesia). Jakarta: Prenhallindo.

Zeithaml, Parasuraman \& Berry. 1990. Delivering Quality Service. New York: The Free Press. 